\title{
RAPD analysis of phomopsis fruit rot resistance in eggplant advanced lines
}

\author{
Marzia Bilkiss ${ }^{\mathrm{a}}$, Rahat Akhter ${ }^{\mathrm{a}}$, Mirza Mofazzal Islam ${ }^{\mathrm{b}}$, M. Ibrahim Khalil ${ }^{\mathrm{c}}$ and M. \\ Bahadur Meah
}

Dept. of Plant Pathology, Bangladesh Agricultural University, Mymensingh

${ }^{b}$ Plant Breeding Division, Bangladesh Institute of Nuclear Agriculture, Mymensingh

Plant Pathology Division, Bangladesh Institute of Nuclear Agriculture, Mymensingh, Bangladesh

\begin{abstract}
Ten lines of eggplant ( $F_{3}$ to $F_{7}$ ) derived from the crossing BAU Begun-1(resistant variety) with Dohazari G and Laffa $S$ (susceptible cultivars) were evaluated for disease resistance and genotypic performances. Two lines of different characters from each generation were selected and inoculated with Phomopsis vexans under confined field condition at fruiting stage. The inoculated genotypes exhibited differential disease reaction. Per-cent fruit infection ranged from $2.77 \%$ to $4.1 \%$. All the lines were found to be resistant to phomopsis fruit rot indicating the inheritance of resistance trait of donor parent BAU begun-1 to the offspring. Random Amplified Polymorphic DNA (RAPD) technique was used as a tool for assessing genetic variation and relationships among the genotypes. Amplification with three decamer primers generated 13 bands of which 11 (84.62\%) were polymorphic. The highest intra-variety similarity indices $\left(S_{i}\right)$ value was found for Laffa purple globose of $F_{7}$ plants and Dohazari green long of $F_{4}$. The coefficient of gene differentiation $\left(G_{s t}\right)$ was 1.00 reflecting the existence of high level of genetic variations among the genotypes. Comparatively higher genetic distance (0.7466) was observed between Dohazari green long of $F_{6}$ vs Laffa green globose of $F_{6}$ and the higher genetic identity (0.9870) was found in Dohazari green long of $F_{6} v s$ Laffa green globose of $F_{5}$. The dendrogram (UPGMA) constructed from Nei's genetic distance produced two main clusters of the ten genotypes. The advanced lines can be released as variety after yield trial and also the genetic variation and relatedness to disease reaction as assessed using $R A P D$ marker could be potential sources for further development of $P$. vexans resistant variety in terms of fruit color and shape.
\end{abstract}

Key words: Eggplant, Fruit rot resistance, Phomopsis vexans and RAPD

Please cite this article as: Bilkiss, M., Akhter, R., Islam, M. M., Khalil, M. I. \& Meah, M. B. (2016). RAPD analysis of phomopsis fruit rot resistance in eggplant advanced lines. Journal of Bioscience and Agriculture Research, 06(01), 530-540.

This article is distributed under terms of a Creative Common Attribution 4.0 International License.

\section{Introduction}

Eggplant (Solanum melongena L.), one of the most popular vegetable crops of Bangladesh is attacked by fruit rot disease caused by Phomopsis vexans, a major constraints in successful cultivation of eggplant in Bangladesh (Das, 1998). The pathogen is seed-borne, can survive in the soil for long time 
(Kalda et al. 1977). The disease is reported to cause $15-20 \%$ (30-50\% in severe case) yield loss in Bangladesh (Das, 1998; Khan, 1999) and elsewhere (Mohanty et al. 1995).

Eggplant having Asiatic origin shows more diversity because of presence of many varieties, cultivars, landraces, hybrids, advanced lines and wild races in this region. Eggplants present a high morphogenetic potential that is useful for developmental studies as well as for establishing biotechnological approaches to produce improved varieties. More than 60 cultivars of eggplant are grown in Bangladesh which shows a wide variation in fruit shape, size, colour and their reaction to disease and insects (Meah et al. 2007). The disease can effectively be controlled by spraying fungicides which provokes environment pollution. Keeping in mind the hazards of chemical use, searching the source of resistance revealed the existence of variation in eggplant cultivars of Bangladesh against $P$. vexans (Islam, 2006).

RAPD technique has been successfully used for the study of genetic variability analysis in different crops including different species of Solanum in Bangladesh and other countries (Khalil et al. 2013; Laila et al. 2012; Sharmin et al. 2011; Kabir, 2007; Islam, 2006; Fukuan et al. 2003) who characterized resistant and susceptible cultivars of eggplant along with their interspecific offspring in Bangladesh. BAU Begun-1, resistant variety was crossed with two popular commercial susceptible varieties of eggplant e.g. Dohazari $G$ and Laffa $S$ and got plants of $F_{1}$ to $F_{7}$ lines, those were selfed. Their phenotypic, morphological and genetic characters have been studied and their reaction to Phomopsis vexans were tested (Sharmin et al. 2011; Rahman et al. 2010; Uddin, 2010; Kabir, 2007; Islam, 2006). The present research work was undertaken to observe the morphogenetic characters of $F_{3}$ to $F_{7}$ eggplant lines derived from crosses between BAU Begun-1 with Laffa and Dohazari and confirm the inheritance of resistant trait at molecular level.

\section{Materials and Methods}

The field experiment was conducted in the field laboratory of the Department of Plant Pathology, Bangladesh Agricultural University, Mymensingh during the cropping season Rabi (October 2011 to April, 2012) (Ahmed et al. 1998). The in vitro experiments were conducted at the Plant Disease Clinic, IPM Laboratory and net house, Department of Plant Pathology, Bangladesh Agricultural University, Mymensingh and Biotechnology Laboratory; Plant Breeding Division, Bangladesh Institute of Nuclear Agriculture, Mymensingh.

Source of seed, seedling raising and transplantation: Two lines of different morphological characters from each of $F_{3}$ to $F_{7}$ generation were selected. The selected line characteristics were: $F_{3}-$ Laffa purple globose and Dohazari green long, $\mathrm{F}_{4}$ - Dohazari green long and Laffa purple globose, $\mathrm{F}_{5}$ Dohazari green long and Laffa green globose, $\mathrm{F}_{6}$ - Dohazari green long and Laffa green globose, $\mathrm{F}_{7}-$ Dohazari green long and Laffa purple globose. The materials were obtained from IPM Lab, Department of Plant Pathology, Bangladesh Agricultural University, Mymensingh, Bangladesh.

Seedlings were raised in the net house in plastic trays with proper care and management. Trays were prepared by mixing soil, sand, and cow dung. Twenty-eight days old healthy seedlings were transplanted in the main experimental field. The experiment was designed in a Randomized Complete Block Design (RCBD) with three replications in the Field. In each subplot, four seedlings were planted maintaining $60 \mathrm{~cm}$ distance between plants and $60 \mathrm{~cm}$ between lines. Fertilizers and manures were applied in the experimental field as per guideline of BARC (Anon. 2005). Weeding, irrigation and other intercultural operations were done whenever necessary.

Inoculation of eggplant by Phomopsis vexans: The plants in the field were inoculated at the flowering stage and again at the fruiting stage. Seventy milliliter spore suspension ( $\left.5 \times 10^{6} \mathrm{spore} / \mathrm{ml}\right)$ prepared with all Phomopsis vexans isolates available at IPM Lab, was sprayed on each plant. The spraying was done at afternoon. Inoculated plants were kept moist and covered with transparent polythene sheet for 24 hours for ensuring better infection. 
One plot of four plants from each advance line was kept uninoculated (control). Culturing P. vexans isolates and preparation of spore suspension were done following the procedure of Islam (2006).

Assessment of Phomopsis fruit rot: After inoculation, symptoms on fruits were observed at sevenday interval up to 21 days. Data on fruit infection (\%) were recorded and the disease severity was calculated according to the standard rating scale (1-5) (Islam et al. 1990).

Harvesting and data recording: The characters responsible for yield of eggplant were studied and the data were collected at fruiting stage. The mature fruits were harvested at the edible stage at an interval of seven days. Four fruits per entry were allowed to ripe and seeds were collected from them for growing plants in the next year.

Statistical analysis: All the characters were analyzed according to design used to find out the statistical significance following Steel and Torrie (1960) and differences between the genotypes were performed by Duncan's Multiple Range Test (DMRT).

Molecular characterization of $F_{3}$ to $F_{7}$ population of eggplant through RAPD analysis: Molecular characterization of the ten lines was done through random amplified polymorphic DNA (RAPD) technique. Fresh leaf samples collected from the 20 days old seedlings were used as a source of genomic DNA. Modified CTAB mini-prep method was followed to extract DNA from leaf samples (Kabir, 2007).

Approximately, $2 \mathrm{~g}$ of leaf tissues were cut into small pieces and taken into a $1.5 \mathrm{ml}$ Eppendorf tube. For digestion, $670 \mu \mathrm{l}$ extraction buffer $(50 \mathrm{mM}$ Tris- $\mathrm{HCl}, 25 \mathrm{~mm}$ Ethyline di-amine tetra acetic acid, 300 $\mathrm{mM} \mathrm{NaCl}$ ) $40 \mu \mathrm{l}$ SDS ( Sodium Dodecyl Sulphate) were taken into a tube and grind with the help of pre cooled mortar pestle. The grinded samples were vortexed for 20 seconds for proper mixing and incubated at $65^{\circ} \mathrm{C}$ for 10 minutes in hot water bath. $100 \mu \mathrm{l} \mathrm{NaCl}$ and $100 \mu \mathrm{l}$ CTAB were added in the samples and then again incubated at the same temperature $\left(65^{\circ} \mathrm{C}\right)$ for 10 minutes for proper digestion. After that the suspension was transferred to another tube and $900 \mu$ l chloroform (chloroform: isomylalcohol: $24: 1, \mathrm{v} / \mathrm{v}$ ) was added and mixed well by a shaker. To allow precipitation of the cell debris, the content was centrifuged for 15 minutes at $12000 \mathrm{rpm}$ with a micro centrifuge. After that the supernatant was transferred into new Eppendorf tubes and then $600 \mu \mathrm{l}$ ice cold isopropanol was added and shaken slowly. The supernatant was decanted and air dried for at least 1 hour. Pellets were washed with $70 \%$ ethanol $(200 \mu \mathrm{l})$, spinned for 10 minutes at $12000 \mathrm{rpm}$ and then air-dried for $1 / 2$ hours. Then the liquid was completely removed without disturbing the pellet of DNA and air dried. Finally the pellets were resuspended in $30.0 \mu \mathrm{l}$ TE buffer (10 mM Tris-HCl, $1 \mathrm{mM} \mathrm{EDTA})$ and stored at $-20^{\circ} \mathrm{C}$.

The quality of the DNA was verified by electrophoreses on a $0.8 \%$ agarose gel in TBE (Tris-boric acidEDTA) buffer. The concentration of DNA samples was determined using a UV Spectrophotometer at $260 \mathrm{~nm}$.

PCR amplification and Electrophoresis: RAPD amplification reactions were maintained following Williams et al. (1990) with some modifications. Fifteen arbitrary decamer primers (Bengalore Genei, India) were screened against DNA from parental cultivars. Three primers producing good scoreable and reproducible bands were selected for subsequent RAPD analysis of eggplant cultivars and phenotypes (Table 02).

PCR reactions were performed on each DNA sample in a $10 \mu \mathrm{l}$ reaction mixture containing $1 \mathrm{x}$ PCR buffer (10 mM Tris $\mathrm{HCl} \mathrm{pH} \mathrm{8.5,50mM} \mathrm{KCl} \mathrm{and} 15 \mathrm{mM} \mathrm{MgCl}_{2}$ ), $10 \mathrm{mM}$ each dNTPs, 5 pmols primer, $2 \mathrm{U}$ of Taq DNA polymerase (Bengalore Genei, India), $100 \mathrm{ng}$ of genomic DNA and rest amount of sterile deionized water. DNA amplification was carried out in a DNA thermocycler (Biometra, Germany) as 
the following thermal profile: initial denaturation for $3 \mathrm{~min}$ at $94^{\circ} \mathrm{C}$ followed by 41 cycles of $1 \mathrm{~min}$ denaturation at $94^{\circ} \mathrm{C}, 1 \mathrm{~min}$ annealing at $35^{\circ} \mathrm{C}$ and extension at $72^{\circ} \mathrm{C}$ for $2 \mathrm{~min}$. A final extension step at $72^{\circ} \mathrm{C}$ for 7 min was allowed for complete extension of all amplified fragments (Kabir, 2007). The PCR products were kept at $4^{\circ} \mathrm{C}$ until electrophoresis. Reaction mixtures were mixed with $2.0 \mu \mathrm{l} 6 \mathrm{X}$ loading dye. Amplified fragments were separated on a 1.5\% agarose (Bengalore Genei, India) gel in $0.5 \mathrm{X}$ TBE buffer along with 20 bp DNA weight marker (Bengalore Genei, India) for 2 hours at 100V. Gel was stained with Ethidium bromide solution $\left(0.1 \mu \mathrm{g} \mathrm{ml}^{-1}\right)$ for $15 \mathrm{~min}$. Finally fragments were visualized under UV-transilluminator and photographed by Gel Documentation System (Biometra, Germany).

Scoring and Data analysis: Since RAPD markers are dominant; we assumed that each band represented the phenotype at a single allelic locus (Williams et al. 1990). The amplified bands were visually scored as present (1) and absent (0) separately for each individual and each primer. The scores obtained were pooled to create -a single data matrix. This was used to estimate polymorphic loci, Nei's (1972) gene diversity, population differentiation $\left(G_{s t}\right)$, gene flow $\left(N_{m}\right)$, genetic distance (D) and to construct a UPGMA (Unweighted Pair Group Method of Arithmetic Means) dendrogram among populations using a computer program, POPGENE (Version 1 .31) (Yeh et al. 1999).The same program was also used to perform test of homogeneity in different loci between population pairs.

\section{Results and Discussion}

\section{Segregation for disease reaction}

All ten lines of eggplant had 2.77 to $4.10 \%$ fruit infection (Table 01$)$. The bigest lesion size $\left(0.051 \mathrm{~cm}^{2}\right)$ was found in $\mathrm{F}_{3}$ Laffa purple globose where the lowest $\left(0.018 \mathrm{~cm}^{2}\right)$ one was found in $\mathrm{F}_{4}$ Laffa purple globase. Considered the percentage fruit infection and lesion size, all the eggplant advanced lines were graded resistant to Phomopsis vexans (Table 01).

Table 01. Disease reaction of $F_{3}$ to $F_{7}$ lines of eggplants against Phomopsis vexans in situ induced condition during 2011-12

\begin{tabular}{lllll}
\hline Variety & $\begin{array}{l}\text { No. of fruits } \\
\text { inoculated }\end{array}$ & Fruit infection (\%) & $\begin{array}{l}\text { Lesion size (cm2) } \\
\text { on fruits }\end{array}$ & Reaction \\
\hline F3 Laffa purple globose & 142.0 & $3.52 \mathrm{~b}$ & $0.051 \mathrm{a}$ & Resistant \\
F3 Dohazari green long & 135.0 & $2.96 \mathrm{c}$ & $0.044 \mathrm{~b}$ & Resistant \\
F4 Dohazari green long & 150.0 & $3.33 \mathrm{~b}$ & $0.025 \mathrm{e}$ & Resistant \\
F4 Laffa purple globase & 146.0 & $3.42 \mathrm{~b}$ & $0.018 \mathrm{~g}$ & Resistant \\
F5 Dohazari green long & 170.0 & $3.53 \mathrm{~b}$ & $0.039 \mathrm{c}$ & Resistant \\
F5 Laffa green globose & 178.0 & $3.93 \mathrm{a}$ & $0.032 \mathrm{~d}$ & Resistant \\
F6 Dohazari green Long & 175.0 & $2.86 \mathrm{c}$ & $0.022 \mathrm{f}$ & Resistant \\
F6 Laffa green globose & 180.0 & $2.77 \mathrm{c}$ & $0.031 \mathrm{~d}$ & Resistant \\
F7 Dohazari green long & 180.0 & $3.33 \mathrm{~b}$ & $0.026 \mathrm{e}$ & Resistant \\
F7 Laffa purple globose & 195.0 & $4.10 \mathrm{a}$ & $0.042 \mathrm{~b}$ & Resistant \\
\hline LSD0.05 & 0.309 & 0.0021 & \\
\hline Level of significance & & 5.40 & 3.83 & \\
\hline CV\% & &
\end{tabular}




\section{Molecular characterization of $F_{3}$ to $F_{4}$ lines of Eggplant through RAPD analysis}

Among the 15 primers initially tested OPA03, OPA04 and OPC05 primers yielded comparatively maximum number of amplification products with high intensity and clear bands. The number of fragments amplified per primer varied (Photograph 1, 2 and 3).

In ten eggplant lines, the selected three primers generated 13 bands. Out of the 13 bands, 11 bands $(84.62 \%)$ were polymorphic and 2 bands $(15.38 \%)$ were monomorphic (Table 02$)$.

The three different primers amplified banding patterns ranging from 4 to 5 . The primer OPC05 produced the highest numbers of polymorphic bands (5). Thus, it showed a higher level of polymorphism (Table 02). The three primers generated 4.33 scorable bands per primer and 3.67 polymorphic RAPD markers per primer. The number of polymorphic band per primer have been reported 4.0, 5.3, 3.3, 4.7 and 5.9 in eggplant by Laila et al. (2012); Sharmin et al. (2011); Rahman et al.(2010); Uddin (2010); Karihaloo et al. (1995) respectively. The difference might be due to the use of different primers and eggplant varieties. Strong and weak bands were produced in the RAPD reactions. Weak bands results from low homology between the primer and the pairing site on the DNA strand (Thormann et al. 1994).

Table 02. RAPD primers with corresponding bands scored and their polymorphic bands observed in 10 lines of eggplants

\begin{tabular}{|c|c|c|c|c|c|}
\hline $\begin{array}{l}\text { Primer } \\
\text { code }\end{array}$ & $\begin{array}{c}\text { Sequences } \\
\left(5^{\prime}-3^{\prime}\right)\end{array}$ & $\begin{array}{c}\text { Number of } \\
\text { bands scored }\end{array}$ & $\begin{array}{c}\text { Size range } \\
\text { (bp) }\end{array}$ & $\begin{array}{c}\text { Number of } \\
\text { polymorphic bands }\end{array}$ & $\begin{array}{c}\text { Polymorphic } \\
\text { loci }(\%)\end{array}$ \\
\hline OPA03 & AGT CAG CCA C & 4 & $300-650$ & 3 & \\
\hline OPA04 & AAT CGG GCT G & 4 & $100-600$ & 3 & 84.62 \\
\hline OPC05 & GAT GAC CGC C & 5 & $200-650$ & 5 & \\
\hline Total & & 13 & & 11 & \\
\hline Average & & 4.33 & & 3.67 & \\
\hline
\end{tabular}

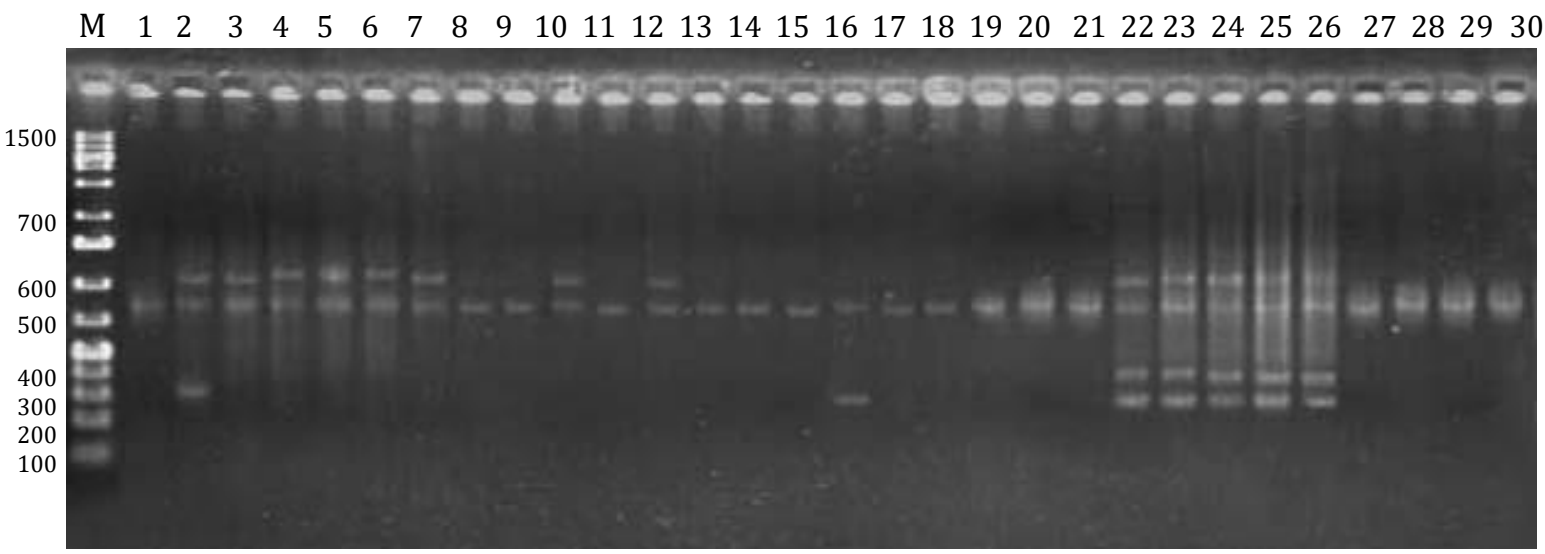

Photograph 01. RAPD profiles of 10 lines using primer OPA03 (Lane 1 (M): 20 bp ladder, Lane 1-3: F3 Laffa green globose, Lane 4-6: F3 Dohazari green long, Lane 7-9: F4 Dohazari Green Long, Lane 10-12: F4 Laffa Purple Globose, Lane 13-15: F5 Dohazari Green Long, Lane 16-18: F5 Laffa Green Globose, Lane 19-21: F6 Dohazari Green Long, Lane 22-24: F6 Laffa Green Globose, Lane 25-27: F7 Dohazari Green Long, Lane 28-30: F7 Laffa Purple Globose on agarose gel. 


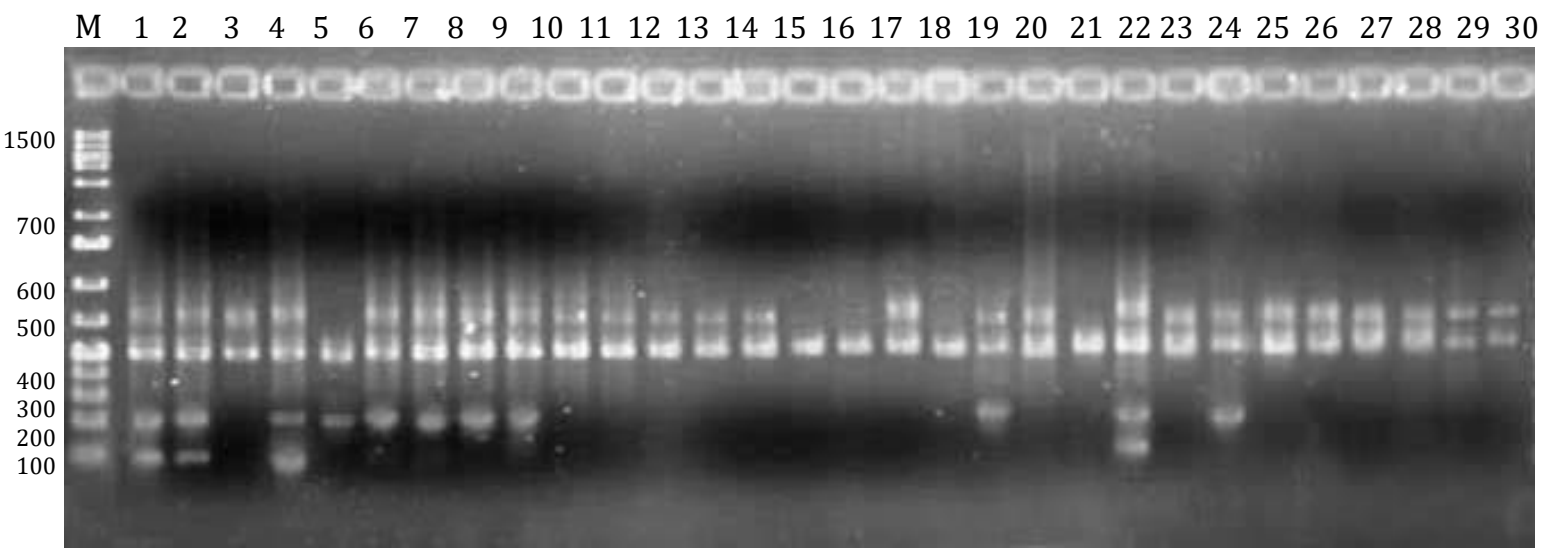

Photograph 02. RAPD profiles of 10 lines using primer OPA04 (Lane 1 (M): 20 bp ladder, Lane 1-3: F3 Laffa green globose, Lane 4-6: F3 Dohazari green long, Lane 7-9: F4 Dohazari Green Long, Lane 1012: F4 Laffa Purple Globose, Lane 13-15: F5 Dohazari Green Long, Lane 16-18: F5 Laffa Green Globose, Lane 19-21: F6 Dohazari Green Long, Lane 22-24: F6 Laffa Green Globose, Lane 25-27: F7 Dohazari Green Long, Lane 28-30: F7 Laffa Purple Globose on agarose gel.

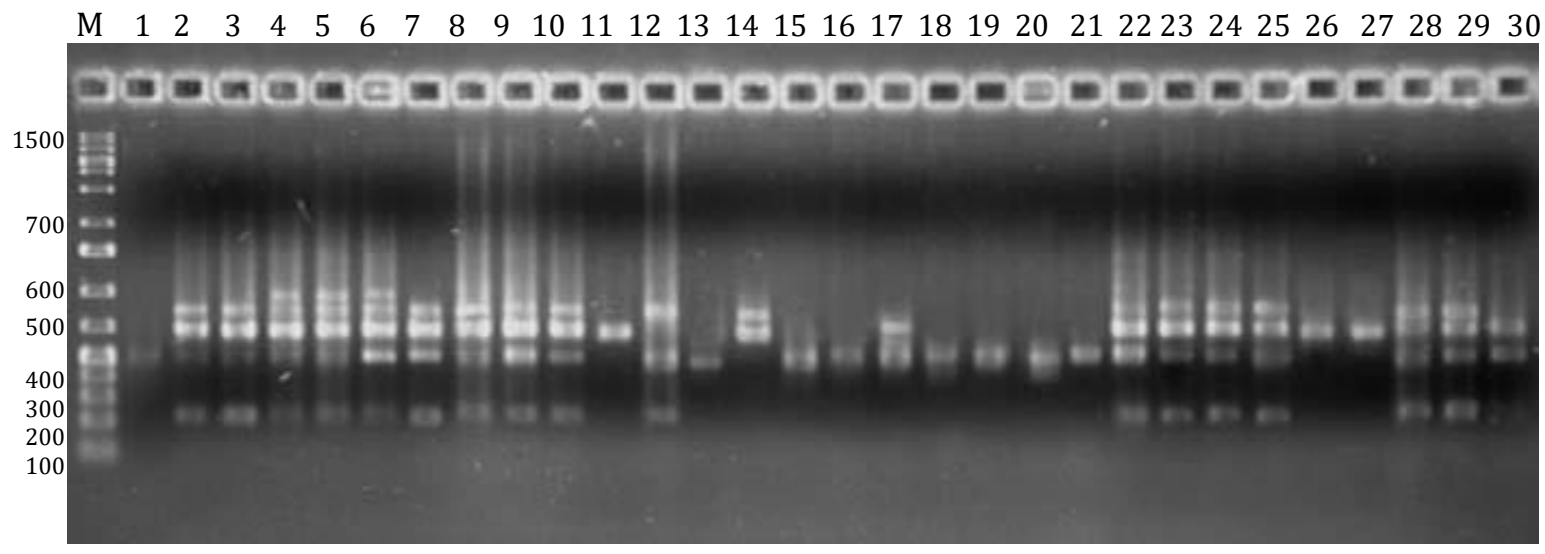

Photograph 03. RAPD profiles of 10 lines using primer OPC05 (Lane 1 (M): 20 bp ladder, Lane 1-3: F3 Laffa green globose, Lane 4-6: F3 Dohazari green long, Lane 7-9: F4 Dohazari Green Long, Lane 1012: F4 Laffa Purple Globose, Lane 13-15: F5 Dohazari Green Long, Lane 16-18: F5 Laffa Green Globose, Lane 19-21: F6 Dohazari Green Long, Lane 22-24: F6 Laffa Green Globose, Lane 25-27: F7 Dohazari Green Long, Lane 28-30: F7 Laffa Purple Globose on agarose gel.

Similar level of polymorphism expressed by arbitrary primers compared to reports of the RAPD studies are available, e.g. in rice (67\%) (Ko et al. 1994), in wheat (78\%) (Sivolap et al. 1997), and in maize (72.2\%) (Valdmar et al. 2004). Varieties having lower similarity are less homogenous group. The highest intra-variety similarity indices $\left(\mathrm{S}_{\mathrm{i}}\right)$ value was found for Dohazri Green Long of F4 plants and Laffa Purple Globose of $F_{7}(92.59 \%)$ followed by Laffa Green Globose of $F_{6}$, Dohazari green long of $\mathrm{F}_{6}$ and Dohazari green long of $\mathrm{F}_{3}$ (Table 03). 
Table 03. Summary of the band sharing based on percentage similarity indices within and between individuals of 10 varieties of eggplant

\begin{tabular}{lllll}
\hline \multirow{2}{*}{ Variety } & \multicolumn{4}{c}{ Band sharing values (\%) } \\
\cline { 2 - 5 } & OPA03 & OPA04 & OPC05 & Average $\mathrm{S}_{\mathrm{i}}(\%)$ \\
\hline $\mathrm{F}_{3}$ Laffa purple globose & 65.56 & 77.78 & 63.33 & 68.89 \\
$\mathrm{~F}_{3}$ Dohazari green long & 100.00 & 77.46 & 100.00 & 92.49 \\
$\mathrm{~F}_{4}$ Dohazari green long & 77.78 & 100.00 & 100.00 & 92.59 \\
$\mathrm{~F}_{4}$ Laffa purple globose & 77.78 & 100.00 & 50.24 & 76.01 \\
$\mathrm{~F}_{5}$ Dohazari green long & 100.00 & 77.78 & 55.55 & 77.78 \\
$\mathrm{~F}_{5}$ Laffa green globose & 77.78 & 77.78 & 77.78 & 77.78 \\
$\mathrm{~F}_{6}$ Dohazari green long & 100.00 & 65.56 & 100.00 & 88.52 \\
$\mathrm{~F}_{6}$ Laffa green globose & 100.00 & 77.46 & 100.00 & 92.49 \\
$\mathrm{~F}_{7}$ Dohazari green long & 60.00 & 100.00 & 60.00 & 73.33 \\
$\mathrm{~F}_{7}$ Laffa purple globose & 100.00 & 100.00 & 77.78 & 92.59 \\
\hline
\end{tabular}

Si: similarity between individuals of the same variety.

\section{Gene diversity and frequency of polymorphic loci}

Overall average gene diversity across all varieties for all loci studies was 0.299 . High level of gene diversity value and Shannon's Information index was found in locus 0PC05-2 (0.497 and 0.690 respectively). The lowest level of gene diversity value and Shannon's Information index was found in locus OPA04-4 (0.145 and 0.276 respectively) (Table 04).

Table 04. Estimates of genetic variation: number and proportion of Polymorph loci, gene diversity and Shannon's Information index obtained in different eggplant genotypes

\begin{tabular}{lcccc}
\hline Variety & $\begin{array}{c}\text { No. of } \\
\text { polymorphic } \\
\text { loci }\end{array}$ & $\begin{array}{c}\text { Proportion of } \\
\text { polymorphic loci } \\
(\%)\end{array}$ & $\begin{array}{c}\text { Gene } \\
\text { diversity } \\
(\mathrm{h})\end{array}$ & $\begin{array}{c}\text { Shannon's } \\
\text { Information index } \\
(\mathrm{I})\end{array}$ \\
\hline $\mathrm{F}_{3}$ Laffa purple globose & 7 & 53.85 & 0.248 & 0.351 \\
$\mathrm{~F}_{3}$ Dohazari green long & 2 & 15.38 & 0.060 & 0.089 \\
$\mathrm{~F}_{4}$ Dohazari green long & 1 & 7.69 & 0.023 & 0.036 \\
$\mathrm{~F}_{4}$ Laffa purple globose & 5 & 38.46 & 0.187 & 0.262 \\
F $_{5}$ Dohazari green long & 4 & 30.77 & 0.121 & 0.178 \\
F $_{5}$ Laffa green globose & 3 & 23.08 & 0.069 & 0.110 \\
$\mathrm{~F}_{6}$ Dohazari green long & 2 & 15.38 & 0.060 & 0.089 \\
$\mathrm{~F}_{6}$ Laffa green globose & 2 & 15.38 & 0.060 & 0.089 \\
$\mathrm{~F}_{7}$ Dohazari green long & 6 & 46.15 & 0.181 & 0.267 \\
$\mathrm{~F}_{7}$ Laffa purple globose & 2 & 15.38 & 0.075 & 0.104 \\
\hline
\end{tabular}

The number and proportion of polymorphic loci was found highest in Laffa purple globose of $\mathrm{F}_{3}$ (53.85\%). Dohazari green long of $\mathrm{F}_{4}$ obtai ned 1 polymorphic locus (7.69\%). The highest proportion of Nei's gene diversity (h) value and Shannon's Information index (I) were found in $\mathrm{F}_{3}$ Laffa purple globose which was 0.248 and 0.351 respectively. On the other hand, the lowest proportion of polymorphic loci and Nei's gene diversity value were found in Dohazari green long of $\mathrm{F}_{4}$. The DNA polymorphisms are detected by band presence versus band absence and the absence of band may be caused by failure to prime a site in some individuals due to nucleotide sequence difference or by insertions or deletions between priming sites (Clark and Langigan, 1993).

\section{Genetic distance and genetic identity}

The values of pair-wise comparisons of Nei's (1972) genetic distance (D) between varieties were 
computed from combined data for the three primers ranged from 0.0131 to 0.7466 (Table 05). Comparatively higher genetic distance (0.7466) was observed between Dohazari green long of $\mathrm{F}_{6}$ vs Laffa green globose of $F_{6}$. The lowest genetic distance (0.0131) was found in Laffa green globose of $F_{5}$ vs. Dohazari green long of $\mathrm{F}_{6}$ genotype pair. Considering the genetic distance values, the varieties were genetically different from each other. Genetic identity between varieties was found for the 3 primers, ranged from 0.4740 to 0.9870 . Comparatively, the higher genetic identity (0.9870) was found in Dohazari green long of $F_{6}$ vs Laffa green globose of $F_{5}$ and the lowest genetic identity (0.4740) was observed between Laffa green globose of $\mathrm{F}_{6}$ vs Dohazari green long of $\mathrm{F}_{6}$.

Table 05. Summary of Nei's (1972) genetic identity (above diagonal) and genetic distance (below diagonal) values for 10 variety pairs of eggplant advanced lines

\begin{tabular}{|c|c|c|c|c|c|c|c|c|c|c|}
\hline 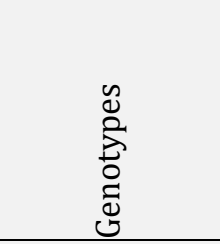 & 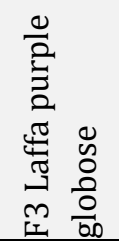 & 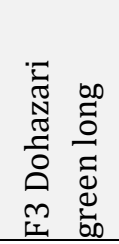 & 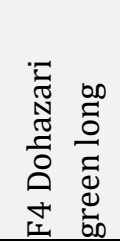 & 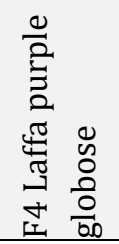 & 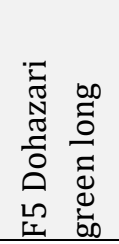 & 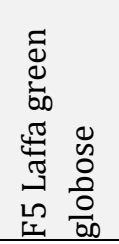 & 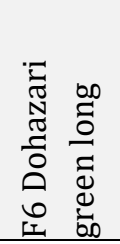 & 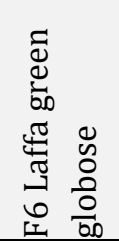 & 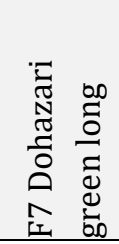 & 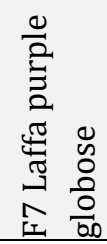 \\
\hline $\begin{array}{l}\text { F3 Laffa purple } \\
\text { globose }\end{array}$ & $* * * *$ & 0.7233 & 0.8647 & 0.9295 & 0.8583 & 0.8570 & 0.8856 & 0.7264 & 0.8334 & 0.9221 \\
\hline $\begin{array}{l}\text { F3 Dohazari } \\
\text { green long }\end{array}$ & 0.3240 & $* * * *$ & 0.8369 & 0.6474 & 0.5180 & 0.5236 & 0.5332 & 0.6998 & 0.5586 & 0.6672 \\
\hline $\begin{array}{l}\text { F4 Dohazari } \\
\text { green long }\end{array}$ & 0.1453 & 0.1781 & $* * * *$ & 0.7978 & 0.6665 & 0.6453 & 0.6763 & 0.7566 & 0.7102 & 0.8628 \\
\hline $\begin{array}{l}\text { F4 Laffa purple } \\
\text { globose }\end{array}$ & 0.0732 & 0.4347 & 0.2258 & $* * * *$ & 0.9275 & 0.8584 & 0.8781 & 0.6611 & 0.9187 & 0.9271 \\
\hline $\begin{array}{l}\text { F5 Dohazari } \\
\text { green long }\end{array}$ & 0.1528 & 0.6579 & 0.4057 & 0.0753 & $* * * *$ & 0.9615 & 0.9638 & 0.4746 & 0.8531 & 0.8664 \\
\hline $\begin{array}{l}\text { F5 Laffa green } \\
\text { globose }\end{array}$ & 0.1543 & 0.6470 & 0.4380 & 0.1527 & 0.0393 & $* * * *$ & 0.9870 & 0.4890 & 0.7833 & 0.8571 \\
\hline $\begin{array}{l}\text { F6 Dohazari } \\
\text { green long }\end{array}$ & 0.1215 & 0.6288 & 0.3911 & 0.1301 & 0.0369 & 0.0131 & $* * * *$ & 0.4740 & 0.7710 & 0.8577 \\
\hline $\begin{array}{l}\text { F6 Laffa green } \\
\text { globose }\end{array}$ & 0.3197 & 0.3570 & 0.2789 & 0.4139 & 0.7452 & 0.7154 & 0.7466 & $* * * *$ & 0.7205 & 0.6799 \\
\hline $\begin{array}{l}\text { F7 Dohazari } \\
\text { green long }\end{array}$ & 0.1822 & 0.5823 & 0.3423 & 0.0848 & 0.1589 & 0.2442 & 0.2600 & 0.3278 & $* * * *$ & 0.8854 \\
\hline $\begin{array}{l}\text { F7 Laffa purple } \\
\text { globose }\end{array}$ & 0.0811 & 0.4047 & 0.1476 & 0.0757 & 0.1434 & 0.1542 & 0.1535 & 0.3858 & 0.1217 & $* * * *$ \\
\hline
\end{tabular}

\section{Dendrogram of ten advanced lines of eggplant}

Dendrogram based on Nei's (1972) genetic distance using Unweighted Pair Group Method of Arithmetic Means (UPGMA) indicated segregation of the ten genotypes of eggplant into two main clusters (Figure $01)$. Seven lines grouped into cluster 1 while three lines grouped in cluster 2 . In cluster 1 , there were two sub-clusters. In sub-cluster 1, there were four lines and in sub-cluster II, there were three lines. Again the genotypes in sub-clusters formed sub-sub clusters.

Laffa purple globose $\left(\mathrm{F}_{3}\right)$, Laffa purple globose $\left(\mathrm{F}_{4}\right)$, Dohazari green long $\left(\mathrm{F}_{5}\right)$, Laffa green globose $\left(\mathrm{F}_{5}\right)$, Dohazari green long $\left(\mathrm{F}_{6}\right)$, Dohazari green long $\left(\mathrm{F}_{7}\right)$ and Laffa purple globose $\left(\mathrm{F}_{7}\right)$ formed one cluster which means they are similar in some characters. On the other hand, Dohazari green long $\left(\mathrm{F}_{3}\right)$, Dohazari green long $\left(\mathrm{F}_{4}\right)$ and Laffa green globose $\left(\mathrm{F}_{6}\right)$ under study formed another cluster showing similarities in some characters. 


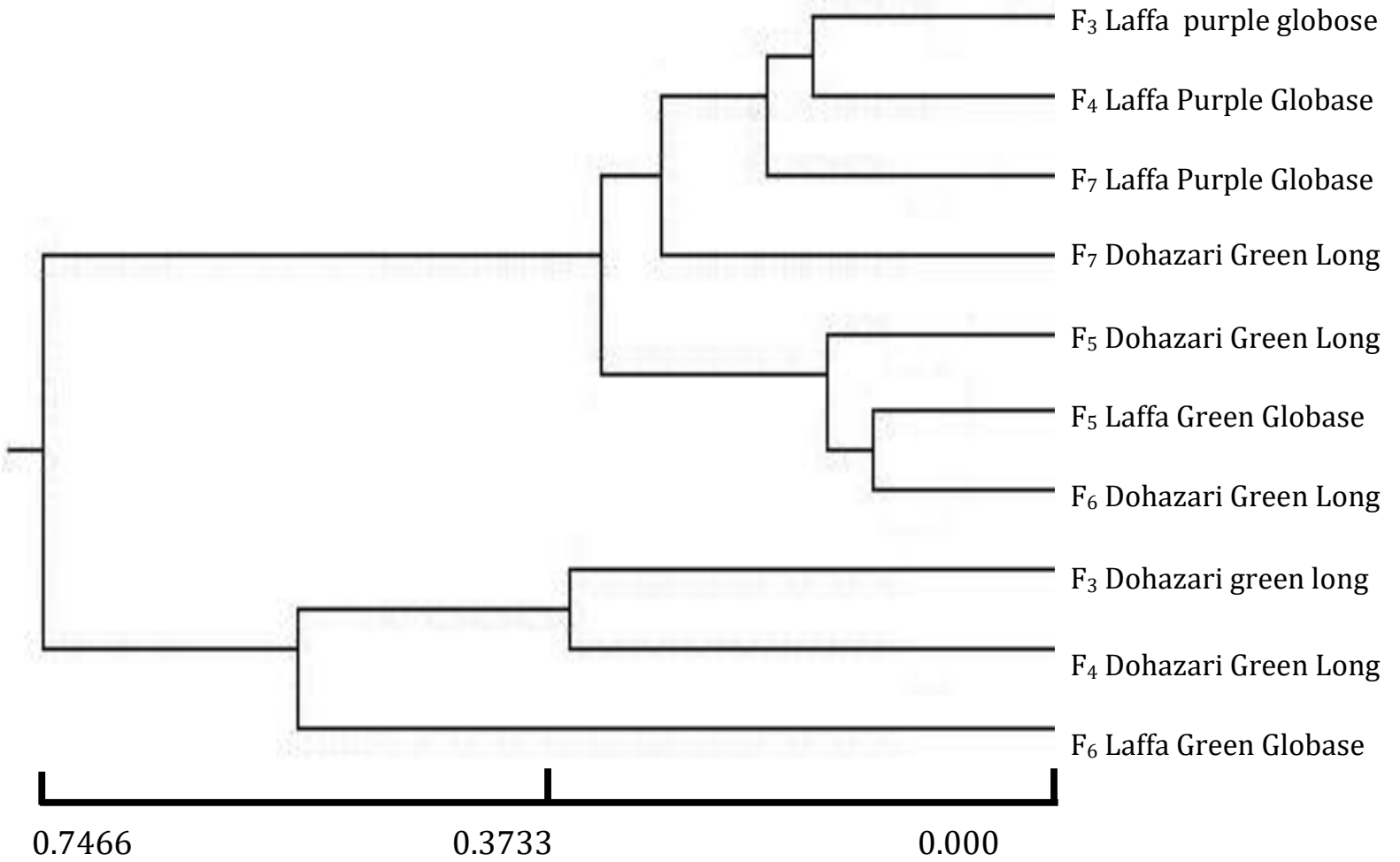

Figure 01. UPGMA dendrogram based on Nei's (1972) genetic distance summarizing the data on differentiation between 10 genotypes, according to RAPD analysis.

\section{Conclusion}

All the advanced lines from $\mathrm{F}_{3}$ to $\mathrm{F}_{7}$ displayed resistance to Phomopsis vexans, the cause of Phomopsis blight and fruit rot of eggplant. The descendants of Laffa cross or Dohazari cross were expected to pour into same cluster separately which was not observed in RAPD analysis. This might be attributed to some agronomic characters shared by the individual lines aggregated in one cluster. With primers OPA03 and OPA04, the 10 lines have shared a common band of 500-600bp and 400-500 bp respectively all through $\mathrm{F}_{3}$ to $\mathrm{F}_{7}$. This may be considered a common character the lines have inherited from the resistant parent BAU begun 1, might be the resistance trait which need further molecular analysis with this band.

\section{Acknowledgement}

Financial aid to this research work through USDA grant BG-ARS-122 is gratefully acknowledged.

\section{Reference}

[1]. Ahmed, Z. U., Begum, S. N. \& Begum, S. (1998). Two new mungbean varieties- Binamoog-3 and Binamoog-4 for cultivation in Bangladesh. Bangladesh Journal of Nuclear Agriculture, 14, 53-58.

[2]. Anonymous, (2005). Fertilizer Recommendation Guide, Bangladesh Agricultural Research Council, Farmgate, Dhaka. p.108.

[3]. Clark, A. G. \& Langigan C. M. S. (1993). Prospects for estimating nucleotide divergence with RAPDs. Molecular Biology and Evolution, 10, 1096-1111.

[4]. Das, B. H. (1998). Studies on Phomopsis fruit rot of brinjal. An M.S. thesis submitted to the Department of Plant Pathology. Bangladesh Agricultural University, Mymensingh. pp. 29-64. 
[5]. Fukuan, Z., Gao, X. H., Cheng, G. H., Fran, S. X. \& Ying, Y. (2003). RAPD analysis and identification of chilling resistance of cellular variant of the eggplant. Acta Agriculturae Boreali Sinica, 18, 1719.

[6]. Islam, S. K., Sitansu, P. \& Pan, S. (1990). Efficacy of humidity and temperature on Phomopsis fruit rot of brinjal (Solanum melongena). Environment and Ecology, 8(4), 1309-1310.

[7]. Islam, M. M. (2006). Molecular characterization of Phomopsis vexans and Solanum melongena and transfer of a Phomopsis resistance trait to cultivar dohazari. A Ph. D. thesis, Department of Plant Pathology, Bangladesh Agricultural University, Mymensingh-2202. p.160.

[8]. Kabir, M. M. (2007). Molecular Characterization of $F_{3}$ offspring of eggplant crosses for resistance to phomopsis blight and Fruit rot. An M.S. thesis submitted to the Dept. of Plant Pathology. Bangladesh Agricultural University, Mymensingh. pp. 100-102.

[9]. Kalda, T. S., Swarup, V. \& Choudhury, B. (1977). Resistance to Phomopsis blight in eggplant. Vegetable Sci. India, 4(2), 90-101.

[10]. Karihaloo, J. I., Brauner, S. \& Gottlieb, L. D. (1995). Random amplified polymorphic DNA variation in the eggplant, Solanum melongena L. (Solanaceae). Theoretical and Applied Genetics., 90, 767770. http://dx.doi.org/10.1007/bf00222010

[11]. Khalil, M. I., Meah, M. B. \& Islam, M. M. (2013). Morphological and molecular characterization of eggplant lines for resistant to phomopsis blight and fruit rot. International Journal of Agricultural Research, Innovation and Technology, 3(1), 35-46. http://dx.doi.org/10.3329/ijarit.v3i1.16053

[12]. Khan, N. U. (1999). Studies on epidemiology, seed-borne nature and management of Phomopsis fruit rot of brinjal. M. S. thesis. Dept. of Plant Pathology, Bangladesh Agricultural University, Mymensingh. p. 134.

[13]. Ko, H. L., Cowan, D. C., Henry, R. J., Graham, G. C., Blakeney, A. B. \& Lewin, L. G. (1994). RAPD analysis of Australian rice (Oryza sativa L.) varieties. Euphytica, 80, 179-189. http://dx.doi.org/10.1007/BF00039649

[14]. Laila, R., Siddiqua, M. K., Khalil, I., Robin, A. H. K. \& Meah, M. B. (2012). Molecular characterization of Solanum melongena using RAPD marker for collar rots resistance. International Research Journal of Applied Life Sciences, 1 (4), 38-65.

[15]. Meah, M. B. (2007). Eggplants of Bangladesh. IPM laboratory, Dept. of Plant Pathology. Bangladesh Agricultural University, Mymensingh. pp. 1-27.

[16]. Mohanty, A. K., Kar, A. K. \& Sitti, P. N. (1995). Efficacy of crude plant extracts of some selected plants in controlling brinjal blight and fruit rot pathogen, phomopsis vexans. Crop Research, 3, 447-448.

[17]. Nei, M. (1972). Genetic distance between populations. American Naturalist, 106, 283-292. http://dx.doi.org/10.1086/282771

[18]. Rahman, M., Meah, M. B., Begum, S.N. \& Ullah, C. (2010). Molecular characterization of $F_{3}, F_{4}$ and $\mathrm{F}_{5}$ population of eggplant for resistance to Phomopsis vexans. Bangladesh Journal of Crop Science, 21(1 \& 2), 13-20.

[19]. Sharmin, D., Khalil, M. I., Begum, S. N. \& Meah, M. B. (2011). Molecular characterization of eggplant crosses by using RAPD analysis. International Journal of Sustainable Crop Production, 6(1), 22-28.

[20]. Sivolap, Y. M., Kutsevich, L. I., Palamarchuk, A. I. \& Totsky, V. N. (1997). Molecular genetic polymorphism of winter durum wheat determined by polymerase chain reaction with arbitrary primers. Russian Agricultural Science, 1, 9-13.

[21]. Steel, R. G. D. \& Torrie, J. H. (1960). Principles and procedures of statistics. McGraw Hill Book Co. Inc. New York. pp. 107-109.

[22]. Thormann, C. E., Ferreira, M. E., Camargo, L. E. A., Tivang, J. G. \& Osborn, T. C. (1994). Comparison of RFLP and RAPD markers for estimating genetic relationships within and among cruciferous species. Theoretical and Applied Genetics, 88, 973-980. http://dx.doi.org/10.1007/BF00220804

[23]. Uddin, M. K. (2010). Molecular characterization of $F_{7}$ eggplant lines for resistance to phomopsis fruit rot. M. S. thesis. Department of Plant Pathology, Bangladesh Agricultural University, Mymensingh.

[24]. Valdmar, P. C., Ruas, F., Moreira, M. P. \& Paulo, M. R. (2004). Genetic diversity among maize (Zea mays L.) landraces assessed by RAPD markers. Genetics and Molecular Biology, 27, 2-4. 
[25]. Williams, J. G. K., Kubclik, A. R., Livak, K. J., Rafalski, J. A. \& Tingey, S. V. (1990). DNA polymorphisms amplified by arbitrary primers are useful as genetic markers. Nucleic Acids Research, 18, 6531-6535. http://dx.doi.org/10.1093/nar/18.22.6531

[26]. Yeh, F. C., Yang R. C., Boyle, T. B. J., Ye, Z. H. \& Mao, J. X. (1999). POPGENE. The user-friendly software for population genetics analysis. Molecular Biology and Biotechnology Centre, University of Albetra, Canada.

\section{Submit article and publish with Journal BiNET.}

Key Features:

$\checkmark \quad$ Faster processing and review of article

$\checkmark \quad$ Quick review and editorial tasks

$\checkmark \quad$ International editorial and review board

$\checkmark \quad 21$ business day's rapid publication

$\checkmark \quad$ View and read articles powered by Scribd

$\checkmark$ Greater audience readership is ensured for all article

$\checkmark \quad$ Indexing and bibliographic integration of article

$\checkmark \quad$ Social sharing enabled article

Submit article (or email to submit@ journalbinet.com): http://www.journalbinet.com/article-submission-form.html 